\title{
Enhancement of monoclonal antibody productivity by promoting active hypothermic growth in hybridoma cells
}

\begin{abstract}
BACKGROUND: Many reports have suggested that mild hypothermic culture conditions improve the specific monoclonal antibody $(\mathrm{mAb})$ productivity of mammalian cells. The effect of active hypothermic growth on the mAb productivity of the hybridoma C2E7 was investigated. Hybridoma growth under hypothermic conditions $\left(32{ }^{\circ} \mathrm{C}\right)$ was stimulated by supplementation of the culture medium with high serum concentrations (up to $30 \%$ ).

RESULTS: Specific and volumetric mAb productivity of a stimulated, active growth, mildly hypothermic hybridoma culture (30\% FBS supplemented, $32{ }^{\circ} \mathrm{C}$ ) were 1.38 - and 1.34-fold greater than the control culture (10\% FBS supplemented, $\left.37^{\circ} \mathrm{C}\right)$. The enhanced specific $\mathrm{mAb}$ productivity under hypothermic conditions was associated with an increase in IgM mRNA levels during both the lag and early exponential phases of hypothermic growth.
\end{abstract}

CONCLUSION: Stimulation of hybridoma growth under mildly hypothermic conditions increased both the specific and volumetric mAb productivity of hybridoma cells.

Keyword: Hypothermic growth; Hybridoma; Monoclonal antibody; Specific productivity 